\title{
PENGUATAN MATA KULIAH PENDIDIKAN AGAMA ISLAM DI PERGURUAN TINGGI UMUM
}

\begin{abstract}
Yahya Aziz*
Abstrak

Tulisan ini membahas penguatan mata kuliah Pendidikan Agama Islam (PAI) di UPM SOSHUM ITS, pertanyaan yang dijawab dalam tulisan ini adalah bagaimanakah bentuk-bentuk upaya penguatan PAI di UPM SOSHUM ITS, untuk memperoleh data tentang pertanyaan tersebut digunakaan observasi dan wawancara langsung. Alokasi waktu belajar 2 sks untuk mata kuliah PAI di UPM SOSHUM sungguh amat minim dan kurang sekali, untuk itu dibuatlah cara/metode agar mata kuliah yang dibina (PAI) mencapai sasaran yaitu dengan jalan penguatan mata kuliah PAI melalui kegiatan extra kurikuler yaitu: pendalaman Al-Qur'an, Halaqoh dan mentoring. Adapun dampak positif yang berkembang selama ini adanya penguatan PAI adalah mahasiswa aktif dan kritis bertanya, rasa ingin tahu persoalan agama Islam dan mahasiswa mempunyai ketrampilan memecahkan belajar sesuai dengan falsafah pembelajaran yang harus diorientasikan ke peserta didik (mahasiswa).
\end{abstract}

Kata kunci: penguatan, Pendidikan Agama Islam (PAl), ekstrakurikuler dan halaqoh

Pendidikan merupakan pilar yang penting dalam menuntut setiap perubahan. Sebagai pilar atau dasar bagi perubahan maka pendidikan mempunyai beban berat untuk mengupayakan perubahan tersebut dan telah terbukti dalam sejarah Indonesia maupun dunia, bahwa pendidikan adalah agent of change menuju perbaikan taraf berfikir dan perubahan status dalam hidup masyarakat. Pendidikan juga merupakan proses transformasi budaya dan nilai-nilai luhur kepribadian yang dilaksanakan secara sistematis dan terprogram. Masalah pendidikan merupakan masalah dinamik seiring dengan perkembangan zaman dan budaya manusia. Usaha-usaha perbaikan dalam pendidikan mulai dari faktor pendidik, sarana pendidikan, lingkungan pendidikan, sistem pendidikan yang senantiasa dilakukan oleh praktisi pendidikan. Semua itu adalah termasuk upaya dan usaha manusia dalam pendidikan yang bertujuan memanusiakan manusia (Karim, 1991: 28), (Paolo Faire, 2000).

Derasnya arus informasi sekarang ini mengakibatkan dunia seakan-akan semakin sempit dan mengglobal, sehingga menjadikan persaingan hidup antara individu dan kelompok semakin menjadi cepat sehingga mengakibatkan lenturnya

* Dosen IAIN Sunan Ampel Surabaya

jsh Jurnal Sosial Humaniora, Vol 4 No.2, November 2011 
nilai-nilai keagamaan, kepribadian individu, moral masyarakat dan bangsa. (Ancok, 1995: , Hasbullah, 1996: , Mulkhan, 2002). Dalam masa seperti ini dibutuhkan suatu kualitas individu dan masyarakat yang kokoh dalam arti individu dan masyarakat yang sehat, mandiri, beriman dan bertaqwa, cinta tanah air, menguasai ilmu dan teknologi serta mempunyai kecakapan dalam hidup, untuk itu menjadi tugas dari pendidikan agama (PAI) untuk mewujudkannya (Brodjonegoro, 2002).

Mata kuliah Pendidikan Agama Islam dipandang sebagai elemen vital dalam sistem pendidikan di Perguruan Tinggi Umum (PTU). Kerena itu dalam setiap upaya perbaikan mutu pendidikan tidak lepas dari penguatan mata kuliah. Penguatan mata kuliah PAI saat ini memang merupakan suatu hal yang mendesak untuk dilakukan mengingat berbagai perkembangan ilmu dan teknologi serta arus informasi yang sedemikian cepatnya (Mastuhu, 2002). Dalam kerangka inilah penguatan mata kuliah PAI sebagai alternative yang ditawarkan dalam rangka meningkatkan mutu kualitas untuk membentuk pribadi peserta didik (mahasiswa) (Abbas, 2002).

Pendidikan Agama Islam (PAI) di perguruan tinggi umum (PTU) termasuk ke dalam kelompok mata kuliah Sosial Humaniora (SOSHUM). Di jurusan UPM SOSHUM ITS mata kuliah PAI diberikan dengan beban 2 sks dari sekitar 33-36 sks sosial humaniora. Perencanaan dan pelaksanaan PAI dilakukan oleh koordinator mata kuliah agama Islam yang bersangkutan di bawah koordinasi ketua jurusan UPM SOSHUM. Harapan terhadap Pendidikan Agama Islam (PAI) yang demikian besar di satu pihak, sementara curahan waktu PAI sangan rendah dipihak lain, agar PAI lebih berdaya guna dan memberikan relevansi dengan kehidupan berbangsa dan bernegara serta mempunyai nilai-nilai aktual. Menyadari akan ruang lingkup PAI yang sangat luas sementara jumlah sksnya terbatas ( 2 sks), maka penguatan PAI menjadi salah satu tuntutan.

Adapun permasalahan yang akan dibahas dalam artikel ini sebagai berikut: 1 . Bagaimana gambaran umum mata kuliah Pendidikan Agama Islam di UPM SOSHUM ITS dan apa Visi dan misi PAI di Perguruan Tinggi Umum, 2. Bagaimanakah Upaya-upaya penguatan mata kuliah PAI di UPM SOSHUM ITS, 3. Adakah faktor-faktor pendukung dan penghambat dalam melaksanakan penguatan mata kuliah PAI di UPM SOSHUM ITS, 4. Apakah problematika penguatan mata 
kuliah PAI di UPM SOSHUM ITS dan bagaimana solusinya, 5. Apa dampak penguatan mata kuliah PAI terhadap mahasiswa di UPM SOSHUM.

\section{Gambaran Umum Mata Kuliah PAI Di UPM SOSHUM ITS}

Gambaran umum mata kuliah Pendidikan Agama Islam di Perguruan Tinggi Umum (PTU) telah tersusun berdasarkan hasil lokakarya mata kuliah PAI yang diselenggarakan pada tanggal 27-28 desember 2002 yaitu mata kuliah PAI yang kontekstual. Hal ini menunjukkan bahwa Pendidikan Agama Islam tidak hanya diletakkan dalam lingkup pembenahan (context of justication) melainkan lebih diletakkan dalam lingkup penemuan (context of discovery) yaitu member visi religious bagi ilmu pengetahuan dan teknologi (Tyoso, 2002)

Perkuliahan Pendidikan Agama Islam kontekstual bukan lagi pengulangan pengulangan aspek ritual tetapi lebih berfungsi sebagai penunjuk kearah pengembangan ilmu pengetahuan. Adapun gambaran umum mata kuliah PAI di PTU yang dipakai di jurusan UPM SOSHUM ITS adalah:

1. Konsep Ketuhanan dalam Islam: a. Filsafat Ketuhanan dalam ilmu, b. Sejarah pemikiran manusia tentang tuhan, c. Tuhan menurut agama-agama di dunia, d. Pembuktian wahyu Tuhan. e. Keimanan dan Ketaqwaan, f. Implementasi Iman dan taqwa dalam kehidupan modern

2. Hakekat Manusia menurut Islam: a. Kejadian manusia, b. Eksistensi dan martabat manusia, c. Tanggung jawab manusia sebagai hamba dan kholifah Allah Swt.

3. Hukum, HAM dan Demokrasi dalam Islam: a. Konsep hukum, HAM dan Demokrasi dalam Islam, b. Hukum Islam dan Kontribusi umat Islam dalam perumusan sistem hukum nasional.

4. Etika, Moral dan Akhlaq: a. Makna etika, moral dan akhlaq, b) Karakteristik etika Islam, c) Hubungan tasawuf dengan akhlaq, d) Aktualisasi Akhlaq dalam kehidupan masyarakat.

5. IPTEK dan Seni dalam Islam: a).Pengertian IPTEK dan Seni, b) Integrasi iman, ilmu dan iptek, c) Keutamaan orang-orang yang berilmu, d) Tanggung jawab Ilmuwan terhadap lingkungan. 
6. Kerukunan antar umat beragama: a Islam agama rahmatan lilalamin, b. Ukhuwwah Islamiyah dan Insaniah, c. Kebersamaan dalam plularisme agama.

7. Masyarakat Madani dan Kesejahteraan umat: a. Pengertian masyarakat madani, b. Konsep masyarakat madani dan karekteristiknya, c. Peranan umat Islam dalam mewujudkan masyarakat madani, d. Sistem Ekonomi Islam dan Kesejahteraan Umat, e. Manejemen zakat, infaq, shadaqah dan wakaf.

8. Kebudayaan Islam: a. Konsep kebudayaan Islam, b. Prinsip-prinsip kebudayaan Islam, c. Sejarah intelektual Islam, d. Masjid sebagiai pusat peradaban Islam, e. Nilai-nilai Islam dalam budaya Indonesia.

9. Sistem politik Islam: a. Makna politik Islam, b. Prisip-prinsip dasar politik Islam, d. Kontribusi umat Islam dalam perpolitikan nasional.

Dari uraian di atas, nampak sekali gambaran umum mata kuliah PAI di PTU sudah cukup ideal baik dari segi tujuan dan materi yang disajikan (Hasanah: 2002).

\section{Visi dan misi PAI di Perguruan Tinggu Umum}

Kampus merupakan lingkungan akademik maka kebenaran ilmiah dari waktu ke waktu selalu berubah, yang mendorong insane akademik untuk selalu mengadakan penelitian dan pengembangan. Pendidikan dalam kehidupan berbangsa dan bernegara pada dasarnya merupakan sosialisasi nilai yang dapat mengantarkan dan mengembangkan potensi peserta didik, agar dapat mempersiapkan diri untuk menyongsong masa depan mereka. Pendidikan agama mempunyai focus untuk nilainilai dan norma-norma yang memberi arah, arti dan tujuan hidup manusia. Pendidikan agama membangun solidaritas sosial yang mengantarkan peserta didik untuk tidak mempunyai sifat egois. Dengan demikian pendidikan agama diharapakan mampu mengubah dan mempengaruhi tingkah laku masyarakat dan bangsa (Depag RI, 2002).

Berdasarkan uraian di atas dapat dirumuskan visi pendidikan agama pada perguruan tinggi umum yaitu: "Meningkatkan kualitas SDM sebagai sumber daya insani dan sumber daya pembangunan yang berkualitas". Visi tersebut dapat dijabarkan kedalam misi sebagai berikut: a. Penyelenggaraan Pendidikan Agama Islam (PAI) yang mampu mengungkapkan potensi dasar manusia sebagai sumber 
daya insani menjadi sumber daya pembangunan, b. Penyelenggaraan Pendidikan Agama Islam (PAI) yang menghasilkan cendekiawan muslim mandiri, berkualitas dan berkemampuan menemukan, mengembangkan, dan menerapkan ilmu pengetahuan, teknologi dan seni dengan etos ulul albab (cendikiawan), c. Penyelenggaraan Pendidikan Agama Islam (PAI) yang mendorong terbentuknya dan terpelihara norma dan etika akademik dalam kehidupan kampus. (Kusumah, 2002).

\section{Upaya-upaya penguatan Pendidikan Agama Islam di jurusan UPM SOSHUM}

Untuk mengimbangi jumlah sks Pendidikan Agama Islam (2 sks) yang sedikit ini diperlukan kegiatan-kegiatan extrakurrikuler yang bisa dipelajari di luar bangku kuliah. Hal ini dapat diharapakan dapat relevan antara yang dipelajari dengan yang diamalkan dalam kehidupan sehari-hari. Hal itu sesungguhnya bukan hal yang mudah karena perilaku mahasiswa telah terbentuk sebelumnya dari rumah dan lingkungan. Namun demikian perlu diusahakan lewat proses penalaran dan perbuatan, seperti: Pendalaman Al-qur'an, Halaqoh, dan Mentoring (Saifudin, 2000).

\section{a. Pendalaman Al-qur'an}

Al-Quran merupakan acuan kontitusi kehidupan manusia sekaligus sebagai pembeda antara yang haq dan yang batil, maka mau tidak mau manusia harus mengkaji dan menginternalisasikan pemahamannya dan mengaplikasikan dalam aktifitas sehari-hari demi terwujudnya cita-cita kodrati manusia untuk mencari kehidupan dunia akhirat (Qordlowi, 1995). Mahasiswa muslim di Perguruan Tinggi Umum tentu berkewajiban pula untuk memenuhi ketentuan di atas sebagai bukti atas statemen keislamannya. Lebih jauh lagi terbentuknya sumber daya manusia yang unggul. Sementara sebagian besar mahasiswa muslim di PTU kemampuan pemahaman Al-Qur'annya baru pada tingkat membaca dalam bentuk tekstual. Berangkat dari kenyataan tersebut perlu ditanamkan kajian intensif Al-Qur'an agar lebih mendekati dan mengakrabi kitab suci tersebut (Wawancara: 2004).

Pengalaman penulis ketika mengadakan pendalaman al-qur'an di kampus ITS adalah mengajar dengan metode tarjamah yaitu mengadakan pengamatan kata demi kata atau kalimat demi kalimat, kemudian mengamati arti masing-masing 
selanjutnya memahami terjemahnya perayat. Dalam hal ini dosen pemandu secara sistematis menguraikan poin-poinnya. Untuk mendapatkan hasil yang optimal dan mencapai kajian yang maksimal, maka dalam prakteknya di tempuh cara-cara sebagai berikut: 1. Para peserta mahasiswa dibagi dalam beberapa kelompok belajar yang terdiri maksimal 10 orang yang dipandu oleh seorang instruktur/ustadz atau dosen, 2. Pada setiap akhir tatap muka selalu diadakan evaluasi baik secara individual atau kelompok, 3. Untuk memantapkan hasil kajian dan melancarkan proses belajar mengajar menggunakan Al-qur'an secara langsung, 4. Sementara para dosen/pemandu/instruktur senantiasa menitikberatkan pada sistem "Berbasis Kompetensi" peserta didik. Adapun metode tarjamah ini menggunakan dua metode yaitu: a. Metode global analitik sintetik dan b. Pendekatan dengan sistem Berbasis Kompetensi.

Metode Global Analitik Sintetik, maksud dari metode ini adalah para peserta mahasiswa terlebih dahulu diajak untuk mengamati materi secara global, kemudian instruktur/dosen/ustadz pemandunya mengajak menganalisa kata-katanya kemudian artinya, selanjutnya terjemahannya perayat setelah itu para mahasiswa diajak membicarakan rangkaian yang ada hubungannya antara satu ayat dengan ayat yang lainnya. Pendekatan dengan sistem "Berbasis Kompetensi" yaitu proses belajar mengajar yang berpusat pada peserta didik dengan tahapan sebagai berikut: a. Instruktur/dosen/ustadz memulai dengan membacakan satu ayat kemudian mengartikan kata demi kata dan akhirnya menerjemahkan arti ayat seutuhnya, b. Peserta mahasiswa mula-mula mendengarkan bacaan ustadz/dosen/pemandu sambil memperhatiakan masing-masing kata yang dijelaskan dan sesudah itu menirukan secara kolektif kemudiian secara individual, c. Setelah mencapai beberapa ayat baru diadakan evaluasi. Program kajian intensif al-qur'an di PTU ini pada tahun 20002008 diadakan pada setiap satu bulan sekali pada hari sabtu, dimulai pukul 07.0008.00 (Aziz: 2005).

\section{b. Halaqoh}

Dalam sepuluh tahun terakhir ini kesemarakan kehidupan beragama di tanah air kita telah mendorong tumbuhnya semangat dan motivasi untuk mendalami agama dan ajaran Islam di kalangan umat, khusunya dikalangan mahasiswa di PTU. 
Fenomena ini antara lain ditandai dengan diselenggarakannya berbagi kegiatan yang bernama "HALAQOH". Pengkajian dan pendalaman ajaran Islam baik institusional melalui HIMA Fakultas maupun individual dan kelompok di dalam dan di luar kampus. Kegiatan-kegiatan tersebut pada gilirannya melahirkan berbagai nuansa pemahaman keagamaan atau agama yang berkembang sejalan dengan meningkatnya frekuensi dan bobot keagamaan yang diselenggarakan oleh mereka. Ada beberapa faktor yang dapat diidentifikasi yang melatarbelakangi berkembangnya halaqoh (Pemahaman keagamaan) di kalangan mahasiswa PTU yaitu: 1. Semangat kemurnian agama dan ajaran Islam, 2. Pandangan bahwa Islam adalah 'RAHMATAN LIL'ALAMIN' yang harus di implementasikan secara konkret dalam realitas kehidupan khususnya di bidang ilmu dan teknologi, 3. Pandangan terhadap sistem kemasyarakatan yang diidealisasikan sebagai ummatan wahidah, 4. Sikap ingin membendung kalau tidak dikatakan menentang penetrasi kebudayaan barat dan menunjukkan keunggulan Islam terhadap sekularisme, hedonism dan materialism (Ali, 2002: 250).

Perkembangan halaqoh di PTU seperti yang dapat kami amati di Institut Teknologi Sepuluh Nopember berkaitan erat dengan kualitas wawasan keagamaan yang mereka miliki dan masukan yang mereka terima dari berbagai sumber belajar baik dari dalam maupun luar kampus. Sejauh ini alur utama pemahaman mereka masih dalam berada proses pencarian bentuk pemahaman. Oleh karena itu terdapat kesulitan mengidentifikasi dan mengkategorikan pemahaman keagamaan yang berkembang di kalangan mereka. Namun demikian terdapat gejala pemahaman yang bisa kami amati, sehingga tampak indikasi yang mengisyaratkan polarisasi pemahaman keagamaan mereka. Di satu sisi terdapat pola pemahaman yang bersifat terbuka (inklusif), di sisi lain ada pemahaman yang bersifat tertutup (eksklusif). Mayoritas mahasiswa muslim di ITS cenderung pada pola pemahaman pertama. Sedangkan kecenderungan pola pemahaman kedua adalah minoritas yang tergabung dalam kelompok-kelompok kecil yang terkesan militan. Kelompok-kelompok inilah yang dikategorikan sebagai kelompok sempalan (Wawancara, 2004). 
Adapun cirri-ciri kelompok sempalan adalah: a. Merasa kelompoknya saja yang benar sedang kelompok yang lain dianggap salah, b. Bersifat eksklusif, c. Cenderung agresif terhadap umat di luar kelompoknya, d. Anti terhadap bentuk kemampanan seperti: pemerintah, lembaga dakwah atau organisasi masa contohnya NU, Muhammadiyah dll, e. Anggotanya memiliki disiplin yang tinggi, f). Pengkultusan pada IMAM (Pemimpin), g. Mengadakan lembaga pernikahan sendiri dan melecehkan lembaga pernikahan resmi pemerintah, h. Cenderung tidak mau berkumpul dengan orang lain, i. Berpakaian khas seperti jubah hijau, jilbab hitam atau cadar dan berbicara suka kearab-araban (Romli Arif, 1997: 24-27).

Pengalaman penulis mengisi halaqoh di kampus ITS yang diadakan setiap hari minggu mulai pukul 09.00-10.30 wib dengan berganti-ganti penceramah, salah satu motifasi mereka mengikuti kegiatan ini adalah: 1. Pendalaman agama Islam, 2. Mereka merasa kurang mendapat pengajaran agama Islam di kelas hanya 2 sks, dan 3. Ingin menambah wawasan penguasaan dan pengembangan agama Islam.

Adapun materi yang diajarkan di kegiatan halaqoh ini adalah materi pengembangan yang diajarkan di kelas, yaitu: Tafsir, Hadits, Fiqh dan Perbandingan Agama. Dengan adanya kegiatan halaqoh ini akan menambah penguasaan dan pendalaman Pendidikan Agama Islam di PTU khususnya di ITS.

\section{c. Mentoring}

Menurut Undang-undang sistem pendidikan nasional, bertujuan mencerdaskan kehidupan bangsa dan mengembangkan manusia Indonesia seutuhnya, sebagai manusia beriman dan bertaqwa kepada Allah dan berakhlaq luhur, memiliki pengatahuan dan ketrampilan, kesehatan jasmani dan rohani, kepribadian yang mantap, mandiri serta tanggung jawab kemasyarakatan dan kebangsaan. Untuk itu jenjang pendidikan wajib memuat dan melaksanakan pendidikan agama. Pada pendidikan tinggi, Pendidikan Agama Islam (PAI) masuk dalam mata kuliah SOSHUM (Sosial Humaniora) yang wajib diikuti oleh setiap mahasiswa yang beragama Islam.

Dua Sistem Kredit semester (2 sks) untuk mata kuliah kuliah agama Islam (PAI) di perguruan tinggi umum (PTU) kiranya sangat minim untuk mencapai 
tujuan yang sangat tinggi yaitu terciptanya manusia beriman dan bertaqwa kepada Allah Swt. Untuk itu dicarilah jalan untuk mencapai tujuan tersebut yaitu dilaksanakan "MENTORING” ( baca: pendampingan atau pengawasan, Sastrapaja, 1990: 316), ini merupakan asistensi agama Islam bagi mahasiswa yang mengikuti mata kuliah Pendidikan Agama Islam (PAI). Beberapa hal yang dilaksanakan selama dalam program mentoring adalah: 1. Sepuluh minggu efektif digunakan pendampingan kelompok dengan metode diskusi kelompok dan pemberian wawasan penguatan Pendidikan Agama Islam, 2. Selama program pendampingan, maka instruktur dapat memberikan penugasan-penugasan dalam rangka tercapainya tujuan mentoring, 3. Mentoring adalah pendampingan agama sehingga peserta dalam kelompok ataupun secara personal dapat menyampaikan permasalahanpermasalahan yang dialami sehingga perlu pemecahan.

Tujuan dari mentoring ini mahasiswa diajak untuk memahami dasar-dasar agama Islam. Dengan pemhaman yang dia peroleh diharapkan muncul semangat baru yang membara untuk mengkaji Islam lebih mendalam, ikut berpartisipasi dalam mengembangkan aktifitas dakwah Islam serta termotivasi untuk meraih prestasi akademik yang maksimal (Panitia Mentoring Pusat, ITS, 2002). Peserta kegiatan mentoring adalah mahasiswa baru ITS yang menempuh tahap persiapan diwajibkan mengikuti seluruh aktivitas mentoring sebagai asistensi kuliah Pendidikan Agama Islam secara kelompok, klasikal, maupun seminar, sebagi bukti keabsahan peserta mengikuti mentoring yaitu setiap akhir semester diberi sertifikat.

Adapun kurikulum mentoring terdapat 11 pokok bahasan yaitu: 1. Makna syahadatain; 2. Tuntutan Iman kepada Al-qur'an; 3. Pengantar memahami Tauhidullah; 4. Beriman kepada nabi Muhammad; 5. Akhlaq seorang muslim; 6. Mengenal addin alislam; 7. Pandangan Al-qur'an terhadap manusia; 8. Bersaudara karena Allah; 9. Memahami gozwul fikri; 10. Fiqh Ibadah; dan 11. Peran pemuda dalam dakwah.

Dengan adanya materi mentoring tersebut bagi mahasiswa maka diharapkan mata kuliah Pendidikan Agama Islam (PAI) di kelas mencapai tujuan yaitu sumber daya manusia yang beriman dan berakhlaq luhur (Wawancara, 2004). 


\section{Faktor-faktor Pendukung dan Penghambat Penguatan Mata Kuliah PAI di Jurusan UPM SOSHUM}

Dari serangkaian observasi dan wawancara yang penulis lakukan, kami dapat menganalisa adanya gejala yang menjadi faktor pendukung dan penghambat adanya penguatan mata kuliah PAI di UPM SOSHUM baik itu faktor yang mendukung dan menghambat dapat dibagi menjadi dua yaitu faktor intern dan extern.

Faktor intern adalah faktor yang bersumber dari sistem tersebut, di antaranya:

\section{a. Rektor}

Rektor sebagai leader sangat besar peranannya dalam menentukan langkahlangkah kebijakan di Perguruan Tinggi Umum sebagai institusi di mana ia memimpin. Dengan demikian rektor dituntut untuk bersikap professional. Di UPM SOSHUM yang telah di observasi oleh penulis, ada tidaknya upaya penguatan PAI sedikit banyak tergantung pada rektor yang mensuport kegiatan keagamaan Islam di PTU yang ia pimpin. Hal ini dapat dibuktikan bahwa rektor menjadi faktor pendukung terhadap terlaksanaya penguatan mata kuliah Pendidikan Agama Islam (PAI) karena rektor sebagai leader adalah penentu kebijakan di Perguruan Tinggi Umum (PTU) yang dia pimpin.

\section{b. Dosen Pendidikan Agama Islam}

Dosen Pendidikan Agama Islam sebagi pelaksana dan pemegang otoritas terhadap pelaksanaan program mata kuliah agama Islam yang dituntut bersikap professional. Dosen agama Islam yang bergelar S1, S2, S3 sangatlah menunjang terlaksananya penguatan mata kuliah PAI. Dengan demikian dosen agama dengan perbedaan background pendidikan mereka berpengaruh terhadap upaya penguatan mata kuliah PAI, karena semakin tinggi kemampuan akademis seorang dosen agama semakin tinggi pula intensitas bimbingan mereka kepada mahasiswa. Oleh karena itu dari data tersebut dapat diasumsikan bahwa faktor dosen PAI dapat juga dijadikan faktor pendukung penguatan mata kuliah agama Islam di UPM SOSHUM.

\section{c. Dosen Mata Kuliah lain}

Dalam komunitas dosen agama, semua dosen agama saling berinteraksi satu dengan yang lainnya, demikian juga dengan dosen-dosen yang lainnya. Programprogram pelaksanaan Pendidikan Agama Islam banyak melibatkan individu-individu 
yang lain, karena kalau dikerjakan dosen Pendidikan Agama Islam (PAI) sendiri tidaklah memadai. Keterlibatan dosen mata kuliah yang lain dalam penguatan mata kuliah PAI adalah terletak pada diikutkan atau disisipkan nilai-nilai keagamaan, misalnya seorang dosen kewiraan menerangkan wawasan kebangsaan, bahwasanya seorang pejabat, mahasiswa, teknokrat dalam menjalankan tugasnya harus mempunyai 3 prinsip: a). Berotak cerdas, b). Berhati Nurani, c). Berkepribadian Indonesia, kalau ketiga hal itu tidak seimbang maka yang terjadi kehancuran, pertumpahan darah antar suku, agama, ras dan golongan.

Oleh karena itu penanaman keagamaan pada mahasiswa yang dilakukan oleh dosen mata kuliah lain sangatlah mendukung, dengan demikian dosen mata kuliah lain sedapatnya juga mengetahui tentang ajaran Islam secara mendalam, karena apabila mereka hanya melakukan transfer pengetahuan saja maka output pendidikan hanya mampu dalam bidang duniawi tanpa diimbangi moralitas dalam memutuskan segala keputusan pada pekerjaan kelak. Dengan demikian dosen mata kuliah lain juga sebagai faktor pendukung atas terlaksananya penguatan mata kuliah PAI di UPM SOSHUM ITS (Aziz: 2005).

\section{d. Sarana dan Prasarana}

Faktor internal yang lain adalah sarana dan prasarana yang memadai, baik sarana yang disediakan oleh pihak perguruan tinggi seperti tempat dan alat untuk menunjang kegiatan keagamaan. Keberadaan sarana dan prasarana jelas tidak dapat dipisahkan dengan kelancaran kegiatan apabila sarana dan prasarana tidak lengkap, maka tentunya banyak mendapatkan kemudahan dalam melakukan suatu aktifitas.

Di UPM SOSHUM ITS juga terdapat perpustakaan khusus tentang keislaman. Buku-buku yang tersedia disana memang tidak sebanyak yang ada di perpustakaan masjid. Namun demikian terasa cukup apabila digunakan untuk sarana memperluas wawasan mahasiswa muslim tentang pengetahuan agama.

Adapun yang menjadi faktor penghambat adalah mahasiswa, sebagian kecil mahasiswa ada yang kurang minat dan perhatian terhadap mata kuliah Pendidikan Agama Islam, karena mata kuliah ini bukan mata kuliah inti di ITS, ada juga yang beranggapan bahwa mata kuliah ini adalah mata kuliah servis (mata kuliah tambahan) dan tidak menentukan standar kelulusan bagi mahasiswa. Dengan 
demikian maka sebagian kecil mahasiswa sebagai penghambat atas terlaksananya penguatan mata kuliah PAI di UPM SOSHUM ITS.

Faktor eksternal, adalah factor pendukung di luar sistem akademik. Ada beberapa faktor ektern yang menjadi pendukung penguatan mata kuliah PAI di UPM SOSHUM yaitu: a. Keluarga; yakni keluarga harus mampu mengembangkan nilainilai pendidikan karakter terhadap mahasiswa. Kalau keluarga sudah broken home itu dapat menghambat pembelajaran PAI di kampus. Pengalaman penulis menangani mahasiswa yang tidak bisa konsentrasi mengikuti mata kuliah agama, setelah kami ajak diskusi dari hati ke hati ternyata orang tuanya habis bercerai. b. Pemerintah baik di eksekutif, legeslatif maupun yudikatif di tingkat pusat samapai daerah harus memperlihatkan cara berfikir dan berprilaku yang menunjukkan karakter kebangsaan yang baik sehingga bisa dicontoh oleh mahasiswa. c. Dunia usaha, yakni pelaku usaha harus memperlihatkan tindakan-tindakan yang beretika dan memiliki tanggung jawab serta etika kebangsaan, jangan memberi contoh yang tidak baik kepada mahasiswa, seperti: korupsi dan suap menyuap, d. Media massa; yakni media cetak dan elektronik, diharapkan jangan mengeksploitasi kasus-kasus amoral dan kejahatan besar-besaran agar tidak menginspirasi para mahasiswa untuk melakukan hal yang sama.

Sedangkan factor-faktor eksternal yang menjadi penghambat penguatan mata kuliah Pendidikan Agama Islam (PAI) di perguruan tinggi umum khususnya di UPM SOSHUM ITS yaitu lingkungan sosial budaya (pergaulan). Walaupun sudah ada upaya pembekalan mental yang kuat terhadap mahasiswa, namun ada saja mahasiswa yang terbawa arus budaya barat yang merusak dan meresahkan masyarakat. Misalnya dalam pergaulan sex bebas, menjadi wanita panggilan, bisnis narkoba. Hal ini akibat dari sebagian kecil mahasiswa yang baergaul dengan lingkungan sosial yang kurang respon terhadap kegiatan-kegiatan extrakurikuler di kampus.

\section{Problematika Penguatan Mata Kuliah PAI Di UPM SOSHUM ITS}

Ada beberapa problema dalam penguatan mata kuliah PAI di UPM SOSHUM ITS sebagai berikut: 
a. Problema Alokasi Waktu Belajar Mata Kuliah Pendidikan Agama Islam (PAI) Alokasi waktu dalam kegiatan belajar PAI di UPM SOSHUM ITS disediakan hanya 2 sks, hal tersebut tidak seimbang dengan tuntutan kompetensi peserta didik (mahasiswa). Untuk meraih tujuan pembelajaran tidaklah semudah membalikkan tangan, sebab hakekat kegiatan belajar mengajar sekarang berubah seiring dengan telah berubahnya dasar tujuan program pembelajaran. Di masa lalu tujuan program pembelajaran adalah untuk mendapatkan hasil-hasil yang baik akhir semester, sedangkan tujuan pembelajaran sekarang adalah kompetensi apa yang dapat diraih oleh mahasiswa. Dengan hanya 2 sks tersebut akibatnya tidak tercapainya tujuan pembelajaran secara maximal.

b. Problema Kurangnya Dosen Agama Dan Banyaknya Mahasiswa

Di UPM SOSHUM ITS terdapat hanya kurang lebih 6-7 dosen PAI sedangkan jumlah mahasiswa mencapai kurang lebih 10.089. Di UPM SOSHUM dosen agama (PAI) dalam kegiatannya di tugasi memberikan layanan kepada seluruh mahasiswa ITS yang tersebar pada 5 fakultas dan 22 jurusan. Dengan demikian seorang dosen agama (PAI) mendapat beban mengajar 12-18 sks bahkan lebih. Pengalaman penulis pada tahun 2005-2007 pernah mengajar 14 kelas (28 sks) saat itu 3 dosen agama tetap di UPM SOSHUM sedang menempuh studi s2 di IAIN Sunan Ampel Surabaya. Kondisi yang demikian amat sulit bagi dosen untuk menerapkan konsep belajar mengajar dengan prinsip berbasis kompetensi, lebih-lebih pengajaran dan pendidikan yang berbasis karakter.

Karena mengajar Pendidikan Agama Islam (PAI), pendekatan pembelajaran yang harus diterapkan adalah pendekatan secara individual, kalau tidak dengan (pendekatan individual) sulit bagi dosen agama Islam untuk memotivasi dan mengontrol perkembangan setiap individu mahasiswa yang begitu banyak dan beragam sifatnya. Penulis pernah mengalami mengajar di kelas FTI satu kelas mahasiswanya sekitar 70 orang, idealnya satu kelas 30 orang.

Akibatnya kegiatan belajar mengajar berjalan secara konvensional yaitu hanya mengejar prestasi "nilai baik", bukan untuk mengembangkan kompetensi secara utuh, ukurannya hanyalah nilai harian, UTS, Tugas dan UAS. Sedangkan 
pendekatan untuk mencapai kompetensi dasar terlalu berat dan sulit untuk meraihnya. Keadaan seperti ini tidak menguntungkan bagi keduanya baik bagi mahasiswa maupun dosen agama (PAI).

c. Problema Organisasi Pembelajaran

Yang dimaksud organisasi pembelajaran disini adalah tidak adanya "Placement Test" agama Islam (Al-qur'an) bagi mahasiswa ITS. Sehingga para dosen agama Islam (PAI) mengukur bahwa kemampuan dasar agama Islam (membaca \& menulis al-qur'an) semua mahasiswa sama. Sehingga proses pembelajaran agama Islam di kelas 70\% cenderung ke metode "Ceramah".

Alternatif Solusi Mengatasi Problematika Penguatan Mata Kuliah PAI Di

\section{UPM SOSHUM ITS}

a. Dalam mengatasi problem waktu kegiatan belajar mengajar mata kuliah agama Islam (PAI), maka dosen PAI bekerja sama dengan tim mentor, ta'mir masjid untuk memantau kegiatan extrakurikuler setiap satu minggu sekali yang dilaksanakan pada hari sabtu - minggu pagi. Materi kegiatan extrakurikuler adalah halaqoh, diskusi, dan pendalaman al-qur'an. Kegiatan ini didasari oleh banyaknya mahasiswa yang belum mampu membaca al-qur'an yang baik dan benar dan mengamalkan dalam kehidupan sehari-hari.

b. Dalam mengatasi problem kekurangan dosen Pendidikan Agama Islam (PAI), maka ITS bisa bekerja sama dengan IAIN Sunan Ampel untuk menambah dosen bantuan (dosen dpk) seperti yang dialami penulis mengajar di ITS mulai tahun 1999-2009, atau menambah dosen LB (luar biasa), atau menambah dosen tetap UPM SOSHUM ITS. Idealnya dosen agama Islam (PAI) mengajar cukup 6-12 sks, sehingga dapat mengetahui kompetensi mahasiswa muslim secara utuh melalui pengajaran dan pendidikan yang berbasis karakter.

c. Dalam mengatasi problem organisasi pembelajaran ini idealnya lembaga pendidikan mengadakan "Placement Test" agama Islam, hal ini tidak mungkin karena akan menimbulkan kecurigaan dan iri mata kuliah lain. Maka solusinya adalah dosen Pendidikan Agama Islam mempunyai inisiatif sendiri untuk mengadakan placement test baca tulis Al-qur'an (BCQ), sehingga akan diketahui kemampuan mahasiswa pada tingkat dasar, menengah, dan atas. Dengan cara ini 
insya Allah akan memudahkan organisasi pembelajaran bagi dosen Pendidikan Agama Islam di kelas.

Dari ketiga solusi diatas menurut penulis ada satu hal yang paling penting demi keberhasilan pembelajaran agama (Pendidikan Agama Islam) di ITS yaitu pendidikan keteladanan/suri tauladan (Uswah Hasanah). Mengajar dengan sabar, telaten, tidak pernah marah, masuk kelas 16 pertemuan, disiplin, semangat dan mempunyai dedikasi yang tinggi akan mendorong mahasiswa untuk semangat belajar agama Islam (PAI).

\section{Dampak positif Penguatan Mata kuliah PAI di SOSHUM ITS}

Berdasarkan pengalaman 10 tahun (1999-2009) mengajar di kampus ITS, dan hasil riset penelitian penulis tahun 2004, kami dapat menidentifikasi bahwa alokasi waktu 2 sks untuk mata kuliah agama Islam (PAI) di UPM SOSHUM ITS sungguh amat kurang sekali. Untuk itu perlu mencari jalan agar mata kuliah yang dibina (agama Islam/PAI) mencapai tujuan yaitu penguatan mata kuliah Pendidikan Agama Islam di antaranya melalui kegiatan-kegiatan ekstrakurikuler yaitu pendalaman al-qur'an, halaqoh dan mentoring. Adapun dampak positif yang berkembang selama adanya penguatan mata kuliah PAI di UPM SOSHUM ITS adalah:

a. Mahasiswa Aktif dan Kritis Bertanya

Meskipun belum ada laporan yang menyatakan secara akurat tentang prosentase peningkatan keaktifan dan kekritisan bertanya pada setiap proses belajar mengajar (PBM), tetapi dari hasil evaluasi dan diskusi dosen Pendidikan Agama Islam telah melaporkan bahwa setiap PBM berlangsung terdapat 5 sampai 10 mahasiswa yang mengajukan pertanyaan dengan jumlah pertanyaan 2 sampai 4 pertanyaan permahasiswa.Peningkatan keaktifan mahasiswa bertanya merupakan peristiwa yang amat baik jika dibandingkan mahasiswa pada tingkat yang sama di tahun-tahun ajaran sebelumnya. Secara kualitatif pertanyaan mahasiswa mengalami peningkatan, misalnya pengalaman penulis ketika mengajar di poltek elektronika dan perkapalan pada PBM PAI ; Mengapa terjadi perbedaan huruf alqur'an pada penulisan "bismi” pada "basmalah" yang tidak 
pakai huruf alif dan kata "bismi" pada surat "al-alaq" yang pakai huruf alif? mengapa terjadi demikian? dan di manakah letak perbedaannya?

Pertanyaan-pertanyaan ini merupakan salah satu indikator peningkatan minat mahasiswa terhadap mata kuliah agama Islam (PAI). Banyaknya mahasiswa yang bertanya, jumlah dan mutu pertanyaan oleh setiap mahasiswa tidak lain karena peran dosen PAI dalam proses belajar mengajar tidak lebih sebagai fasilitator dan motivator. Dan yang lebih penting lagi juga respons positif untuk menerima kenyataan ini bahwa meningkatnya jumlah mahasiswa bertanya, jumlah pertanyaannya serta mutu pertanyaannya itu tidak dianggap sebagai mahasiswa yang usil, banyak tanya, atau kritis, tetapi justru para dosen harus meresponnya positif bahwa kondisi ini menjadikan kita harus belajar dari mereka.

b. Rasa Ingin Tahu Persoalan Agama

Bolehkah kita menghadiri perayaan natal dan mengucapkan selamat hari rayanya? Bolehkan seorang wanita jadi presiden? Mengapa di agama Islam ada istilah Islam liberal, Islam inklusif, Islam eksklusif? Dan masih banyak pertanyaan yang serba ingin tahu dan ini bukti dari kekritisan mereka. Ini sebenarnya merupakan bukti logis dan hasil penguatan mata kuliah PAI, maka hendaknya dosen memberikan peluang pada mahasiswa mengembangkan kompetensi dirinya untuk mencari, mengolah dan menemukan sendiri pengetahuan di bawah bimbingan para dosen agama.

c. Ketrampilan memecahkan masalah

Dampak yang menunjukkan bahwa mahasiswa memiliki ketrampilan memecahkan masalah dan memiliki pengalaman belajar itu tidak lain karena para dosen sendiri yang menghendaki setiap proses pembelajaran harus mendekatkan mahasiswa kepada dunia nyata dan kehidupan sehari-hari yang ada sekitarnya. Meningkatnya mahasiswa yang terampil memecahkan masalah karena para dosen agama Islam (PAI) di UPM SOSHUM ITS mengubah paradigmanya dari metode "ceramah" ke "problem solving" atau diskusi. Sehingga mendapatkan sumber belajar tidak hanya di kelas tapi juga diluar kelas. Contoh pengalaman penulis ketika mengajar di kelas statistik kami beri 
permasalahan keterlibatan sebagian kecil mahasiswa terhadap narkoba, ternyata argument-argumen atau gagasan-gagasannya cukup cemerlang. Kalau menurut kami itu karena pengaruh lingkungan, harus ada peran ulama, tokoh masyarakat, pejabat pemerintah yang ikut bertanggung jawab terhadap permasalahan tersebut.

\section{Kesimpulan}

1. Gambaran umum mata kuliah Pendidikan Agama Islam (PAI) di UPM SOSHUM ITS terdiri dari 3 pokok bahasan yaitu: a. Aqidah, b. Syariah dan c. Akhlaq. Dan sejak tahun 2002 mengikuti kurikulum Dirjen Dikti Kemendiknas.

2. Di antara faktor-faktor pendukung dan penghambat dalam melaksanakan penguatan mata kuliah Pendidikan Agama Islam (PAI) di UPM SOSHUM ITS adalah faktor intern dan eksternal. Adapun faktor yang mendukung faktor intern adalah: Rektor, Dosen Pendidikan Agama Islam, Dosen Mata Kuliah lain dan sarana dan prasarana. Sedangkan yang menghambat adalah sebagian kecil mahasiswa yang tidak respon terhadap mata kuliah agama Islam. Adapun faktor eksternal yang mendukung adalah: Keluarga, Pemerintah, Dunia usaha dan Media massa, sedangkan yang menghambat faktor eksternal adalah lingkungan sosial budaya (pergaulan ).

3. Ada 3 Problematika penguatan mata kuliah Pendidikan Agama Islam di UPM SOSHUM ITS yaitu: Problematika alokasi waktu belajar Pendidikan Agama Islam, Problematika kurangnya dosen Pendidikan Agama Islam dan banyaknya mahasiswa dan organisasi pembelajaran.

4. Alternatif solusi dalam mengatasi penguataan mata kuliah Pendidikan Agama Islam adalah: a. Dalam mengatasi problem waktu belajar agama Islam maka dosen Pendidikan Agama Islam bekerja sama dengan tim mentor untuk memantau kegiatan ekstrakurikuler mahasiswa, b. Dalam mengatasi kurangnya dosen agama Islam dan banyaknya mahasiswa maka ITS bisa bekerja sama dengan instansi lain untuk menambah dosen dpk (diperbantukan), dosen luar biasa dan dosen tetap di UPM SOSHUM. c).Dalam mengatasi organisasi pembelajaran Pendidikan Agama Islam (PAI) di ITS, maka dosen agama isla 
Islam mempunyai inisiatif sendiri mengadakan placement test agar mudah dalam mengelola pembelajaran mata kuliah Pendidikan Agama Islam.

5. Adapun dampak positif yang berkembang selama adanya penguatan mata kuliah Pendidikan Agama Islam adalah: a. Mahasiswa aktif dan kritis bertanya, b. Rasa ingin tahu persoalan agama, c. Mahasiswa mempunyai ketrampilan memecahkan masalah.

\section{Daftar Pustaka}

Abbas, Hafidz. "Reformasi Pendidikan Agama Islam di PTU: Visi, misi dan strategi", dalam Dinamika Islam di Perguruan Tinggi, ed. Fuaddudin dan Hasan Bisri, Jakarta: Logos, 2002.

Ali, Muhammad Daud, "Fenomena Sempalan Keagamaan di PTU: Tantangan bagi Pendidikan Agama Islam", dalam Dinamika Pemikiran Islam di Perguruan Tinggi, ed. Fuaddudin dan Hasan Bisri, Jakarta: Logos 2002.

Al-qordlowi, Yusuf, “Karekteristik Islam”, terj. Surabaya: Risalah Gusti , 1995

An-Nahlawi, Abdurrohman, "Prinsip-Prinsip Pendidikan Islam di Sekolah, Keluarga, dan Masyarakat", terj. Bandung: CV. Diponegoro, 1992

Brodjonegoro, Satryo Soemantri, "Strategi Kebijakan Pembinaan Pendidikan Agama Islam (PAI) di PTU”, dalam Dinamika Pemikiran Islam di Perguruan Tinggi, ed. Fuaddudin dan Hasan Bisri, Jakarta: Logos, 2002

Bukhori, Mukhtar, "Spektrum Problematika Pendidikan di Indonesia", Yogyakarta: Tiara Wacana, 1996

Darajat, Zakiah, "Peranan Agama dalam Kesehatan Mental, Jakarta: Gunung Agung, 1989

Depag RI, "Islam Untuk Disiplin Ilmu Hukum, Buku Daras PAI pada PTU”, Jakarta: 2002

Faiere, Paolo, "Pendidikan Kaum Tertindas”, Jakarta: LP3ES, 2000

Hasanah, Uswatun, dkk "Modul Acuan Proses Pembelajaran Mata Kuliah Pengembangan Kepribadian Agama Islam, Jakarta: Dirjen Dikti, 2002

Hasbullah, "Kapita Selekta Pendidikan Islam”, Jakarta: PT. Raja Grafindo Persada, 1996

Kusukah, Aman Wirakarta, "Reformasi PAI di PTU: Visi dan Misi" dalam Dinamika Pemiiran Islam di Perguruan Tinggi, ed. Fuadduddin dan Hasan Bisri, Jakarta: Logos, 2002 
Mastuhu, "Pendidikan Agama Islam di PTU" dalam dinamika Pemikiran Islam di Perhuruan Tinggi”, ed. Fuadduddin dan Hasan Bisri, Jakarta: Logos, 2002

Mukhan, Abdul Munir, "Nalar Spritual Pendidikan, Yogyakarta, Tiara Wacana, 2002

Panitia Mentoring Pusat, “Buku Panduan”, ITS, 2002

Rusli Karim, "Pendidikan Islam Sebagai Upaya Pembebasan Manusia Dalam Pendidikan Islam Di Indonesia antara Cita dan Fakta", Muslih Esa (ed), Pustaka Tiara, Yogyakarta, 1991

Romli, M. Arif, "Peningkatan Kemampuan Pembina Pendidikan Agama Islam Dalam Membina Seksi Kerohanian Islam SMU Negri Se Kodya Surabaya”, LPM, Tp, 1997

Saifudin, Ahmad Muflih, "Reorientasi PAI di PTU dalam Prespektif Moral, dalam Dinamika Pemikiran Islam di Perguruan Tinggi, ed. Fuaddudin dan Hasan Basri, Jakarta: Logos, 2002

Yahya, M.Aziz, "Pendidikan Agama Islam Telaah Penguatan KBK di Perguruan Tinggi”, Surabaya: Pustaka Sandi, 2005. 